\title{
Leiomyosarcoma of the Adrenal Vein
}

\author{
I-Hung Shao, MD; Wei-Chen Lee'1, MD; Tai-Di Chen², MD; Yang-Jen Chiang, MD
}

Leiomyosarcoma of the adrenal gland is extremely rare in the literature. We present a patient with an adrenal leiomyosarcoma originating from the adrenal vein, the pathologic findings and management. A 66-year-old man who was a hepatitis B virus carrier was found to have a huge left suprarenal mass on sonography and computed axial tomography. A huge tumor in the left suprarenal area with a markedly engorged adrenal vein was found during an adrenalectomy. The tumor thrombus extended into the renal vein, close to the inferior vena cava. The left adrenal gland with the whole tumor thrombus was removed completely. Microscopically, the adrenal gland was compressed but not invaded by the spindle cell tumor, which was composed of interlacing fascicles of neoplastic smooth muscle cells. The tumor was localized within the adrenal vein and arose from the venous wall. The patient had no local recurrence for 18 months after en bloc excision of the tumor. We suggest that en bloc excision with a clear and adequate surgical margin is the most important cure procedure for adrenal leiomyosarcoma. (Chang Gung Med J 2012;35:428-31)

Key words: adrenal gland, adrenal tumor, leiomyosarcoma, renal vein thrombus

$\mathrm{L}$ eiomyosarcoma is a malignant tumor which originates from smooth muscle. It can occur in the uterus, bowel, vascular structures, and skin as well as soft tissue and bone. ${ }^{(1)}$ Leiomyosarcoma of the adrenal gland is extremely rare in the literature. We present a patient with an adrenal leiomyosarcoma originating from the adrenal vein and discuss the pathologic findings as well as the management.

\section{CASE REPORT}

A 66-year-old man who was a hepatitis B virus carrier was found to have a huge left suprarenal mass during regular follow-up abdominal sonography. His symptoms included mild abdominal fullness and occasional nausea, but no recent abdominal pain or body weight loss. No abdominal mass could be palpated on physical examination. Computed axial tomography (CAT) revealed a well-defined large mass $(9.5 \times 8 \mathrm{~cm})$ in the left suprarenal area, which extended through the adrenal vein into the left renal vein (Fig. 1).

During surgery, a huge tumor was found in the left suprarenal area, with a markedly engorged adrenal vein about $1.5 \mathrm{~cm}$ in diameter. A part of the tumor with a milky-yellow color impacted the venous lumen as a tumor thrombus. The thrombus extended into the renal vein, almost to the level of the inferior vena cava. The renal vein was opened to expose the $8 \mathrm{~cm}$ tumor thrombus which was completely removed with the left adrenal gland (Fig. 2).

Microscopically, the adrenal gland was compressed but not invaded by the spindle cell tumor, which was composed of interlacing fascicles of neoplastic smooth muscle cells (Fig. 3). The tumor was localized within the adrenal vein and originated from

From the Division of Urology; 'Division of General Surgery, Department of Surgery; ${ }^{2}$ Department of Pathology, Chang Gung Memorial Hospital at Linkou, Chang Gung University College of Medicine, Taoyuan, Taiwan.

Received: Sep. 2, 2011; Accepted: May 11, 2012

Correspondence to: Dr. Yang-Jen Chiang, Division of Urology, Department of Surgery, Chang Gung Memorial Hospital at Linkou. 5, Fusing St., Gueishan Township, Taoyuan County 333, Taiwan (R.O.C.) Tel: 886-3-3281200 ext. 2103; Fax: 886-3-3285818;

E-mail: zorro@cgmh.org.tw 
the venous wall. Immunohistochemical study showed the following which confirmed the final diagnosis of leiomyosarcoma: desmin (+), CD117 $(-)$, smooth muscle actin (+), HMB45 (-), and CD34 $(-)$.

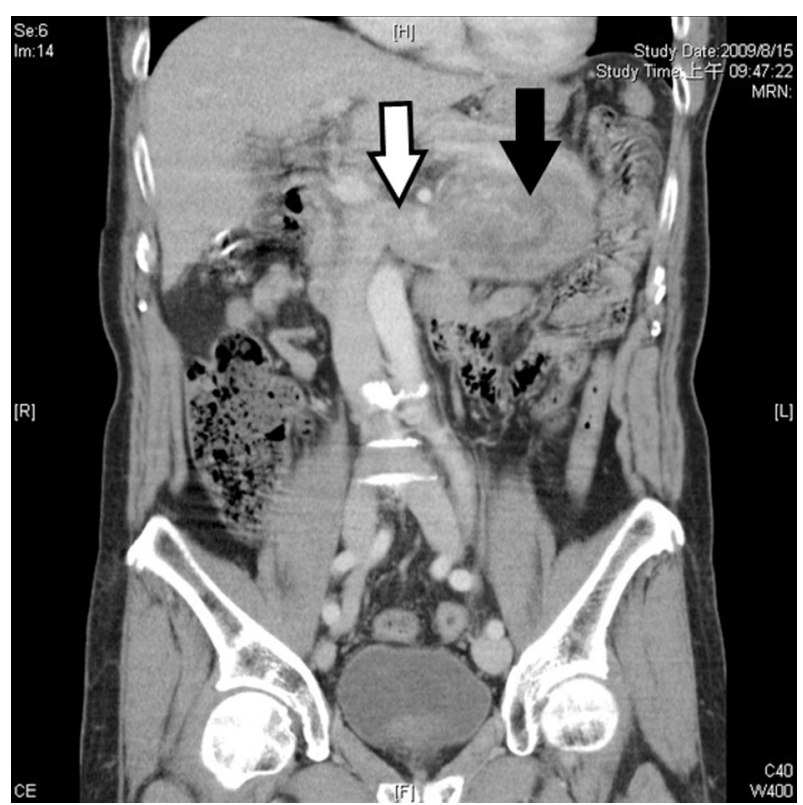

Fig. 1 Computed axial tomography reveals a large left suprarenal tumor (black arrow), with the tumor thrombus extending into the left renal vein (hollow arrow), and almost invading the inferior vena cava.

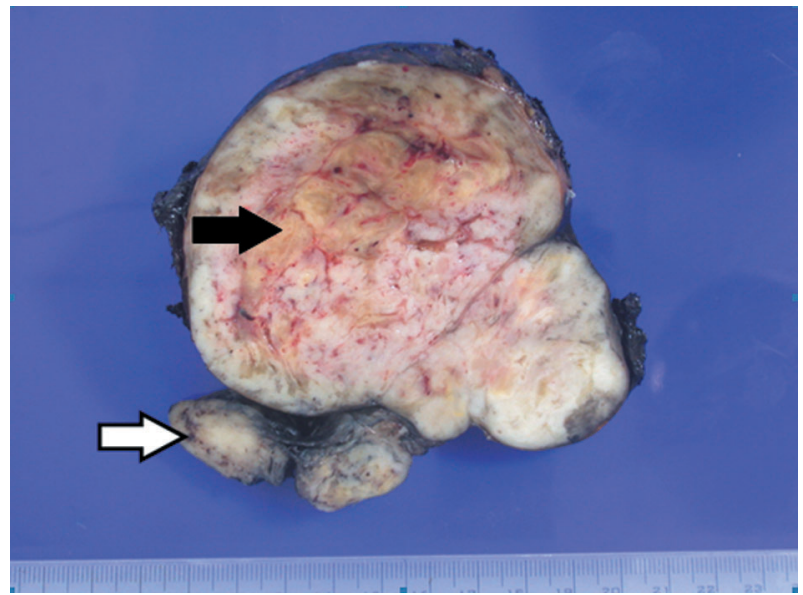

Fig. 2 Gross appearance of the en bloc resected suprarenal mass. The hollow arrow indicates the thrombus in the renal vein, while the black arrow indicates normal adrenal tissue compressed by the tumor.

\section{DISCUSSION}

Leiomyosarcoma is a malignant tumor composed of spindle cells showing smooth muscle features, and is the most common soft tissue sarcoma in adults. The tumor may arise from any structure or organ containing smooth muscle such as the uterus, bowel, vascular structures, and skin as well as soft tissue and bone. More than half of these tumors are located in retroperitoneal or intra-abdominal sites.

Vascular leiomyosarcomas are rare, representing less than $2 \%$ of all leiomyosarcomas, and veins are more likely to be involved. ${ }^{(2)}$ Commonly involved vascular sites include the pulmonary artery and inferior vena cava. Leiomyosarcoma of the adrenal gland is an even rarer tumor, and is proposed to originate from the central adrenal vein or its tributaries.

According to accumulated experience, "en bloc" excision including the locregional lymph nodes with a clear surgical margin is the best management in most vascular leiomyosarcomas. ${ }^{(3)}$ Subsequent reconstruction with vascular grafts may be required after en bloc excision of vessels.

There is no report documenting a consistent advantage of chemotherapy for adrenal leiomyosarcomas, although some authors have suggested radio-

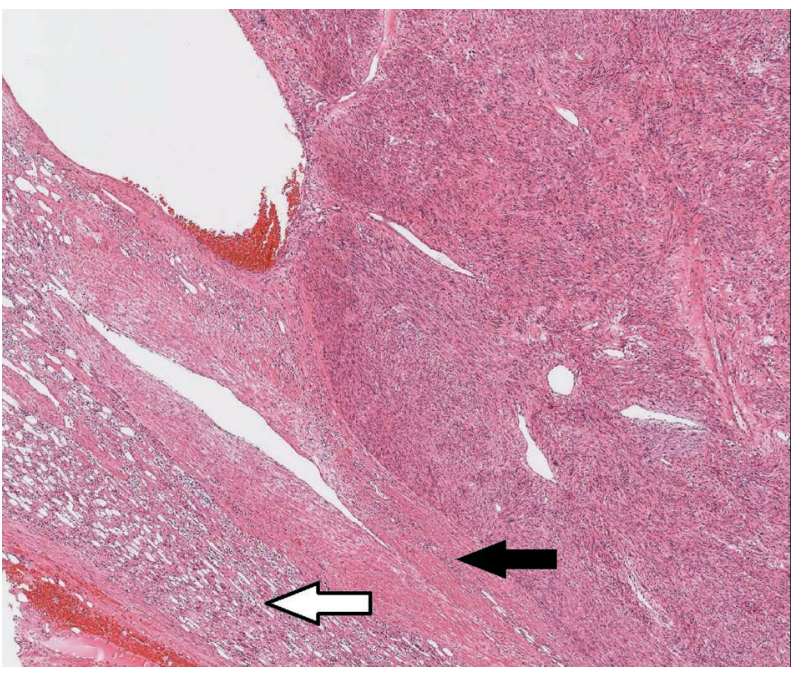

Fig. 3 Malignant smooth muscle cells with prominent atypical nuclei show the typical architecture of interlacing short fascicles within the leiomyosarcoma. The tumor arises from the adrenal vein (black arrow). Normal compressed adrenal gland tissue is seen at the periphery (hollow arrow). 
therapy and chemotherapy might have beneficial effects in controlling local disease and bone pain. ${ }^{(4)}$ Kenney et al. mentioned some benefits with adjuvant or neoadjuvant radiation therapy in retroperitoneal tumors. However, there was no definitive conclusion in these studies. The benefit of chemotherapy for localized retroperitoneal sarcomas is still controversial, and there is a lack of large controlled studies. ${ }^{(5)}$

Mohanty et al reported that adrenal leiomyosarcoma remained localized in 7 cases reported in the literature, with either local recurrence or distant metastasis documented in the other reported 6 cases. ${ }^{(4)}$ Our patient had no local recurrence or metastasis after 18 months follow up with 3 CAT scans. We suggest that en bloc excision with a clear and adequate surgical margin remains the most important principle for cure of adrenal leiomyosarcoma.

\section{REFERENCES}

1. Gustafson P, Willen H, Baldetorp B, Ferno M, Akerman M, Rydholm A. Soft tissue leiomyosarcoma: A population-based epidemiologic and prognostic study of 48 patients, including cellular DNA content. Cancer 1992:70:114-9.

2. Dzsinich C, Gloviczki P, van Heerden JA, Nagorney DM, Pairolero PC, Johnson CM, Hallett JW Jr, Bower TC, Cherry KJ Jr. Primary venous leiomyosarcoma: a rare but lethal disease. J Vasc Surg 1992:15:595-603.

3. Wang TS, Ocal IT, Salem RR, Elefteriades J, Sosa JA. Leiomyosarcoma of the adrenal vein: a novel approach to surgical resection. World J Surg Oncol 2007:5:109.

4. Mohanty SK, Balani JP, Parwani AV. Pleomorphic leiomyosarcoma of the adrenal gland: case report and review of the literature. Urology 2007:70:591 e5-7.

5. Kenney RJ, Cheney R, Stull MA, Kraybill W. Soft tissue sarcomas: current management and future directions. Surg Clin North Am 2009:89:235-47. 


\title{
腎上腺靜脈之平滑肌肉瘤
}

\section{邵翊紘 李威震 ${ }^{1}$ 陳泰迪 ${ }^{2}$ 江仰仁}

\begin{abstract}
遍覽之前的文獻紀錄, 腎上腺的平滑肌肉瘤是一種極度军見的疾病。我們在此報告一例 由腎上腺靜脈所長出的平滑肌肉瘤, 包括其病理發現以及處理方式。一名六十六歲的男性病 患, 因爲定期以超音波追蹤乙型肝炎, 而意外發現位於左側腎上腺的巨大腫瘤。當我們爲其 進行左側腎上腺切除手術時, 可以發現左側的腎上腺靜脈有明顯膨大的現象。癌栓一路延伸 至腎靜脈, 非常接近下腔大靜脈。於是手術中我們將同側腎上腺連同全部的腫瘤一併徹底切 除。在顯微鏡下可以發現, 腎上腺被一個梭狀細胞腫瘤所壓迫, 但是並沒有直接侵犯的證 據。此梭狀細胞腫瘤由許多束狀交錯的增生平滑肌肉細胞所組成。這個腫瘤位在腎上腺靜脈 内, 由靜脈血管壁上所長出。術後經過十八個月的追蹤, 此病患並未發現有復發的情況。對 於腎上腺的平滑肌肉瘤最佳的治療方法, 我們建議在能夠達到乾淨且足夠切除邊界的前提 下，將腫瘤整塊切除。(長庚醫誌 2012;35:428-31)
\end{abstract}

關鍵詞：腎上腺, 腎上腺腫瘤, 平滑肌肉瘤, 腎靜脈癌栓

長庚醫療財團法人林口長庚紀念醫院 泌尿外科系, 1一般外科系, 病理科系

受文日期：民國100年9月2日；接受刊載：民國101年5月11日

通訊作者: 江仰仁醫師, 長庚醫療財團法人林口長庚紀念醫院 泌尿外科系。桃園縣333龜山郷復興街5號。

Tel: (03)3281200轉2103; Fax: (03)3285818; E-mail: zorro@cgmh.org.tw 